\title{
HUBUNGAN KARAKTERISTIK INDIVIDU DENGAN TINDAKAN PENGELASAN DI PT ALIM AMPUH JAYA STEEL SIDOARJO
}

\author{
Vadila Zakky Mahardhika \\ Ikatan Alumni Kesehatan Masyarakat Indonesia \\ Provinsi Jawa Timur \\ Email: vadilazy@gmail.com
}

\begin{abstract}
Work accidents most caused by unsafe practices of workers. Accidents that caused by human's unsafe practices can be learned by analyzing factors underlying a practices as a predisposing factors, reinforcing factors and enabling factors. The purpose of this research was to study factors that associated with the practices of welders in PT Alim Ampuh Jaya Steel Sidoarjo. This research was observational with a cross sectional design. Subject of this research was total population that consist of 20 welders and safety officer. Data obtained from questionnaires, interviews, and observations. Data would be shown in a frequency distribution and cross tabulation between variables. The result showed that elder and longer work length workers had an appropriate practice and not according to the welding procedures and the majority workers who has a good knowledge, didn't work according to the welding procedure. The company is advised to hold a training programs about hot work hazards and providing the welding facilities. The company should review and rewrite the procedure according to the facilities they had.
\end{abstract}

Keywords: individual characteristics, welding practice

\begin{abstract}
ABSTRAK
Kecelakaan kerja dapat terjadi karena kondisi lingkungan kerja yang tidak aman dan perilaku tidak aman pekerja. Berdasarkan hal tersebut, maka untuk meminimalisir tindakan tidak aman yang dilakukan oleh pekerja pengelasan perlu dipelajari karakteristik individu yang berhubungan dengan tindakan pekerja. Tujuan penelitian ini secara umum untuk mempelajari karakteristik individu yang berhubungan dengan tindakan pengelasan di PT Alim Ampuh Jaya Steel. Penelitian ini adalah penelitian deskriptif dengan pendekatan cross sectional. Data primer didapatkan dengan cara observasi, wawancara mendalam dan melalui pengisian lembar kuesioner. Sedangkan data sekunder didapatkan dari PT Alim Ampuh Jaya Steel Sidoarjo. Sasaran dari penelitian ini adalah safety officer dan 20 pekerja pengelasan. Data diolah secara deskriptif dan dijelaskan dalam bentuk narasi. Hasil penelitian menunjukkan bahwa meskipun pekerja memiliki umur yang tua dan masa kerja yang lama, tetap melakukan tindakan yang tidak sesuai dengan prosedur pengelasan dan mayoritas pekerja yang memiliki tingkat pengetahuan baik, seluruhnya melakukan tindakan yang tidak sesuai dengan prosedur. Dari hasil penelitian dapat disarankan agar perusahaan mengadakan program pelatihan mengenai pengelasan dan menyediakan fasilitas penunjang pengelasan. Perusahaan juga disarankan untuk meninjau dan menulis ulang prosedur pengelasan menyesuaikan fasilitas yang telah ada.
\end{abstract}

Kata kunci: karakteristik individu, tindakan pengelasan

\section{PENDAHULUAN}

Kecelakaan kerja merupakan masalah yang serius bagi sebuah perusahaan karena kecelakaan dapat mengakibatkan kerugian yang besar. Kerugian yang diakibatkan oleh kecelakaan kerja bisa berupa kerusakan material, hilangnya jam kerja, dan timbulnya korban jiwa. Timbulnya korban jiwa adalah kerugian yang sangat besar. Kerugian yang langsung nampak dan dapat terlihat dari timbulnya kecelakaan kerja adalah biaya pengobatan dan kompensasi kecelakaan, sedangkan biaya tidak langsung yang tidak nampak antara lain kerusakan alat produksi, penataan manajemen keselamatan yang lebih baik, penghentian alat produksi, dan hilangnya waktu kerja (Ramli, 2009).

Data yang dikumpulkan oleh PT Jamsostek tahun 2005 menyebutkan bahwa sebanyak 31,9\% dari seluruh kecelakaan kerja di Indonesia terjadi di industri yang bergerak di bidang konstruksi dan fabrikasi. Mayoritas kecelakaan tersebut diakibatkan oleh tindakan tidak aman pekerja dengan tidak mematuhi program dan peraturan keselamatan dan kesehatan kerja (K3) perusahaan.

Kecelakaan kerja dapat terjadi akibat kondisi lingkungan kerja yang tidak aman dan perilaku pekerja tidak aman yang bersumber dari manusia 
itu sendiri saat melakukan kegiatan di tempat kerja dan menangani alat atau material. Heinrich (1980), memaparkan bahwa 88\% kecelakaan disebabkan oleh tindakan yang tidak aman dari manusia, sedangkan penyebab lainnya adalah hal yang tidak berkaitan dengan kesalahan manusia, yaitu $10 \%$ disebabkan oleh kondisi atau lingkungan yang tidak aman dan 2\% disebabkan oleh bencana alam. Heinrich menekankan bahwa kecelakaan lebih banyak disebabkan oleh kekeliruan dan kesalahan yang dilakukan oleh manusia.

Tindakan manusia merupakan hasil dari banyak faktor, baik internal (karakteristik dari dalam diri manusia), maupun eksternal (faktor lingkungan). Faktor karakteristik manusia meliputi tingkat kecerdasan, pengetahuan, persepsi, emosi, motivasi, jenis kelamin dan faktor genetik individu. Faktor eksternal atau lingkungan mencakup lingkungan fisik dan nonfisik, diantaranya adalah kebijakan atau peraturan, pengawasan, pelatihan, keteladanan, sosial budaya, kebudayaan, dan ekonomi (Notoatmodjo, 2003).

Penelitian yang dilakukan oleh Maanaiya (2005) pada pekerja di PT. Yamaha Indonesia Motor Manufacturing (YIMM) menunjukkan bahwa faktor internal, yaitu pengalaman kerja, pelatihan, dan kelelahan mempunyai pengaruh terhadap tindakan tidak aman. Hal serupa pada penelitian yang dilakukan oleh Noer (2012), di unit welding PT Gaya Motor Jakarta yang menjelaskan bahwa mayoritas kecelakaan kerja terjadi akibat tindakan tidak aman oleh pekerja. Kecelakaan PT Gaya Motor Jakarta dari pada 2011 terdapat 14 kecelakaan yang mana seluruhnya merupakan kecelakaan yang diakibatkan oleh tindakan tidak aman.

Pencegahan kecelakaan kerja secara tepat dan efisien dapat membantu perusahaan untuk menghindari kerugian materi dan non-materi yang besar. Tindakan tidak aman menurut Green (1980) mayoritas disebabkan oleh tiga faktor, yaitu faktor dari manusia itu sendiri atau faktor predisposisi yang meliputi pendidikan, umur, tingkat pengetahuan dan sikap; faktor pemungkin yang meliputi ketersediaan sarana prasarana; dan faktor penguat yang meliputi kebijakan dan peraturan perusahaan.

Nasrullah dan Tjipto (2014), dalam jurnal penelitiannya pada 41 pekerja bagian West Assembly PT XYZ menjelaskan bahwa sebagian besar pekerja di unit West Assembly PT XYZ sebagian besar melakukan tindakan yang tidak aman atau bekerja dengan tidak mematuhi atau sesuai dengan prosedur yang telah ditetapkan meskipun pekerja memiliki pengetahuan yang baik.

Kejadian kecelakaan yang disebabkan oleh tindakan tidak aman dari pekerja dapat dipelajari dengan mempelajari faktor yang mendasari tindakan seperti faktor internal yaitu karakteristik individu dan faktor eksternal. Berdasarkan hal tersebut, maka untuk meminimalisir tindakan tidak aman yang dilakukan oleh pekerja pengelasan perlu dipelajari karakteristik individu yang berhubungan dengan tindakan pekerja.

PT Alim Ampuh Jaya Steel adalah perusahaan yang bergerak pada bidang manufaktur baja untuk keperluan konstruksi seperti produksi tiang $h$-beam, di mana setiap proses pekerjaan di PT Alm Ampuh Jaya Steel pasti terdapat aktivitas pengelasan karena untuk penggabungan atau assembly dari bahanbahan yang berasal dari plat baja untuk digabung menjadi satu material konstruksi tertentu. PT Alim Ampuh Jaya Steel memiliki 10 gudang produksi atau workshop di mana total seluruh pekerja pengelasan di semua gudang terdapat 20 orang welder atau pekerja pengelasan yang bertugas setiap harinya.

PT Alim Ampuh Jaya Steel telah memiliki dokumen prosedur standar untuk pengelasan yang meliputi kegiatan dan peralatan yang harus disiapkan pekerja dan pengawas pekerjaan sebelum pekerjaan dimulai. Kegiatan seperti menyiapkan work permit, observasi bahaya yang mungkin terjadi dan menyiapkan alat pemadam api ringan atau APAR dan fire blanket telah dijelaskan di dalam prosedur pengelasan PT Alim Ampuh Jaya Steel.

Observasi lapangan menunjukkan bahwa ketersediaan APAR yang belum memadahi yaitu hanya berjumlah 20 buah di seluruh area perusahaan sehingga tidak ada APAR yang tersedia di saat pekerjaan pengelasan berlangsung. Meski dalam prosedur disebutkan bahwa fire blanket harus disediakan saat pekerjaan pengelasan, namun pihak perusahaan belum menyediakan fire blanket tersebut sehingga fire blanket juga tidak tersedia di area pengelasan.

Observasi awal yang telah dilakukan menunjukkan bahwa mayoritas welder selalu memakai APD seperti welding mask; welding gloves; apron; safety shoes; masker; dan baju cover-all. Namun demikian seluruh welder bekerja tanpa ada APAR dan fire blanket di dekatnya yang mana hal ini tidak sesuai dengan apa yang telah tertulis pada prosedur pengelasan PT Alim Ampuh Jaya Steel. Penanggung jawab atau 
supervisor tidak mengeluarkan ijin atau work permit sebelum memulai pekerjaan atau sebelum pekerja mengoperasikan alat.

Pemakaian APD oleh welder ini belum sepenuhnya menjadi acuan bahwa sikap dan tindakan welder baik karena masih banyak ditemukan pekerja pengelasan atau welder yang merokok di area kerja meski dekat dengan tabung gas dan bahan mudah terbakar lainnya. Selain itu beberapa pekerja melakukan pekerjaan di luar job desk nya seperti menjadi grinder dan operator overhead crane, hal ini terjadi karena work permit belum diterapkan di perusahaan. Berdasarkan hal tersebut, kecelakaan bisa saja terjadi dan menimbulkan kerugian bagi perusahaan, sehingga pencegahan harus dilakukan yaitu dengan menganalisa karakteristik individu yang berhubungan dengan tindakan pengelasan.

Tujuan penelitian ini secara umum untuk mempelajari karakteristik individu yang berhubungan dengan tindakan pengelasan. Secara khusus antara lain: mengidentifikasi umur pekerja pengelasan di PT Alim Ampuh Jaya Steel, mengidentifikasi masa kerja pekerja pengelasan di PT Alim Ampuh Jaya Steel, mengidentifikasi tingkat pengetahuan pekerja pengelasan di PT Alim Ampuh Jaya Steel, mengobservasi tindakan pekerja pengelasan, mempelajari hubungan karakteristik individu seperti umur, masa kerja dan tingkat pengetahuan dengan tindakan pekerja.

\section{METODE}

Penelitian dilakukan di PT Alim Ampuh Jaya Steel Waru, Sidoarjo. Penelitian ini dilakukan pada bulan Agustus sampai dengan September 2016. Penelitian ini bersifat observasional sehingga data yang terkumpul dapat dianalisis secara deskriptif dan disajikan dalam bentuk narasi.

Metode yang digunakan selama penelitian berlangsung adalah observasi lapangan, hal ini dilakukan untuk mengamati proses pengelasan di bagian workshop. Rancangan penelitian ini adalah cross sectional dikarenakan penelitian dilaksanakan dalam kurun waktu tertentu.

Data primer didapatkan dengan cara observasi, wawancara mendalam dan melalui pengisian lembar kuesioner. Sedangkan data sekunder didapatkan dari PT Alim Ampuh Jaya Steel Waru, Sidoarjo.

Sasaran dari penelitian ini adalah seorang safety officer dan 20 pekerja pengelasan. Data yang telah dikumpulkan kemudian diolah secara deskriptif dan disajikan dalam bentuk narasi yang akan menggambarkan dari beberapa variabel yang diteliti.

Karakteristik individu meliputi umur, tingkat pendidikan dan masa kerja responden yang diukur dengan menggunakan kuesioner dan hasil yang didapat akan dikategorikan menjadi beberapa kategori. Umur responden akan dikategorikan menjadi 2 kategori yaitu: kategori umur $>34$ tahun dan kategori umur $\leq 34$ tahun. Masa kerja dikategorikan menjadi 2 kategori yaitu: kategori masa kerja $>7$ tahun dan kategori masa kerja $\leq 7$ tahun.

Tingkat pengetahuan pekerja diukur menggunakan kuesioner dengan jumlah pertanyaan 7. Nilai 1 untuk jawaban yang benar dan nilai 0 jika jawaban salah. Pengetahuan diklasifikasikan menjadi 2 kategori, yaitu pengetahuan baik dan pengetahuan kurang baik. Pengetahuan baik yaitu jika total nilai $>$ mean dan pengetahuan kurang baik jika total nilai $\leq$ mean.

Tindakan pekerja pengelasan diukur menggunakan lembar observasi yang dibuat berdasarkan prosedur pengelasan yang telah ada, observasi terhadap seorang pekerja dilaksanakan selama 1 jam pada pagi hari dan 1 jam pada siang hari.

Data yang diperoleh untuk karakteristik individu, tingkat pengetahuan dan tindakan pada pekerja pengelasan disajikan dalam bentuk tabel frekuensi dan diberikan penjelasan narasi. Penggunaan tabulasi silang untuk melihat hubungan antar variabel.

\section{HASIL}

\section{Kebijakan Keselamatan dan Kesehatan Kerja}

Kebijakan keselamatan dan kesehatan kerja akan mengarahkan PT Alim Ampuh jaya Steel dalam menerapkan dan meningkatkan Sistem Manajemen Keselamatan dan Kesehatan Kerja (SMK3) sehingga dapat dipelihara dan ditingkatkan kinerjanya. Chief Executive Officer memastikan bahwa kebijakan keselamatan dan kesehatan kerja: a. Sesuai dengan sifat dan skala risiko K3 Organisasi; b. Mencakup komitmen untuk pencegahan cidera, penyakit dan peningkatan berkelanjutan; c. Mencakup komitmen mematuhi peraturan $\mathrm{K} 3$ dan peraturan lain yang relevan terkait dengan risiko K3; d. Memberi kerangka kerja untuk menetapkan dan meninjau tujuan dan sasaran K3; e. Didokumentasikan, diterapkan dan dipelihara; f. Dikomunikasikan 
kepada semua karyawan dengan tujuan agar mereka menyadari akan kewajiban individu terhadap K3.

Penggunaan alkohol dan obat dapat meningkatkan risiko terhadap kecelakaan. Pemanfaatan dan atau penggunaan obat terlarang atau obat yang dipengaruhi bahan tersebut pada saat bekerja tidak ditoleransi. Kebijakan tersebut akan ditinjau ulang minimum satu kali dalam setahun.

\section{Prosedur Pengelasan PT Alim Ampuh Jaya Steel}

PT Alim Ampuh Jaya Steel telah memiliki prosedur pengelasan yang tergabung dengan beberapa prosedur pekerjaan lainnya dalam dokumen bernama pengendalian operasi. Dokumen pengendalian operasi merupakan gabungan dari beberapa prosedur pekerjaan yang ada di PT Alim Ampuh Jaya Steel yang terlampir pada dokumen OHSAS 18001:2007.

Prosedur pengelasan PT Alim Ampuh Jaya Steel berisi tentang kegiatan dan peralatan yang harus disediakan sebelum memulai pekerjaan, antara lain: Pertama pengawas atau orang lain yang bertanggung jawab harus mengeluarkan ijin kerja panas (hot work permit) sebelum mengijinkan karyawan menggunakan peralatan yang dapat menimbulkan nyala api di tempat-tempat yang dianggap berbahaya karena adanya cairan, uap atau gas yang mudah terbakar. Masa berlaku hot work permit harus tidak boleh lebih lama dari waktu kerja (shift) pemberi ijin. Selanjutnya pekerja harus menggunakan peralatan pelindung diri untuk mengelas seperti sarung tangan las, kaca mata las dan pakaian anti api jika memungkinkan.

Ketiga, para pekerja wajib mengikuti safety meeting terlebih dahulu untuk membahas bahaya yang mungkin timbul dan bagaimana cara mengatasi bahaya serta tindakan yang harus dilakukan jika terjadi keadaan darurat. Keempat, pekerja harus memastikan di sekitar lokasi terdapat alat pemadam kebakaran yang sesuai dengan jenis kebakaran yang mungkin terjadi dan periksa kondisi peralatan pemadam tersebut seperti APAR atau alat pemadam api ringan, pompa air, selang air dan lainnya. Selanjutnya pengawas mengecek lokasi di mana akan dilakukan pekerjaan sebelum pengawas menandatangani ijin kerja panas.

Pekerja juga diharuskan untuk membaca dan memahami prosedur rencana tindakan dalam keadaan bahaya kebakaran yang ada dan memastikan pekerja tahu tugas dalam rencana menghadapi bahaya kebakaran tersebut. Terakhir pekerjaan
Tabel 1. Umur Pekerja Pengelasan Tahun 2016

\begin{tabular}{lcc}
\hline Kategori Umur (tahun) & Frekuensi & \% \\
\hline$>34$ tahun & 9 & 45 \\
$\leq 34$ tahun & 11 & 55 \\
\hline Total & 20 & 100 \\
\hline
\end{tabular}

Tabel 2. Masa Kerja Pekerja Pengelasan Tahun 2016

\begin{tabular}{lcc}
\hline \multicolumn{1}{c}{ Masa Kerja } & Frekuensi & \% \\
\hline$>7$ tahun & 5 & 25 \\
$\leq 7$ tahun & 15 & 75 \\
\hline Total & 20 & 100 \\
\hline
\end{tabular}

pengelasan tidak boleh berada di tempat berbahaya jika memungkinkan. Fire blanket harus dipakai jika terpaksa dilakukan di tempat yang memang mempunyai potensi bahaya kebakaran.

\section{Karakteristik Individu}

Umur

Umur adalah salah satu komponen dari karakteristik individu yang memiliki hubungan dengan tindakan pekerja. Berikut adalah Tabel 1 yang menunjukkan distribusi frekuensi pekerja pengelasan berdasarkan umur di PT Alim Ampuh Jaya Steel tahun 2016.

Tabel 1 menjelaskan bahwa umur dari responden yang paling banyak adalah kategori umur $\leq 34$ tahun yang berjumlah 11 orang $(55 \%)$. Kategori umur $>34$ tahun berjumlah 9 orang (45\%). Umur responden yang paling muda adalah 24 tahun dan umur paling tua adalah 52 tahun.

\section{Masa Kerja}

Masa kerja adalah salah satu komponen dari karakteristik individu yang memiliki hubungan terhadap tindakan pekerja. Berikut adalah Tabel 2 yang menunjukkan distribusi frekuensi pekerja pengelasan berdasarkan masa kerja di PT Alim Ampuh Jaya Steel tahun 2016.

Tabel 2 menjelaskan bahwa masa kerja dari responden sebagian besar adalah kategori $\leq 7$ tahun yang berjumlah 15 orang $(75 \%)$, sedangkan kategori masa kerja $>7$ tahun berjumlah 5 orang $(25 \%)$. Terdapat dua responden yang memiliki masa kerja yang paling singkat yaitu selama 1 tahun dan masa kerja yang paling lama adalah 26 tahun. 
Tabel 3. Tingkat Pengetahuan Pekerja Pengelasan Tahun 2016

\begin{tabular}{lcc}
\hline $\begin{array}{c}\text { Tingkat } \\
\text { Pengetahuan }\end{array}$ & Frekuensi & \% \\
\hline Baik & 13 & 65 \\
Kurang Baik & 7 & 35 \\
\hline Total & 20 & 20 \\
\hline
\end{tabular}

\section{Tingkat Pengetahuan}

Tingkat pengetahuan adalah salah satu komponen dari karakteristik individu yang memiliki hubungan dengan tindakan pekerja. Berikut adalah Tabel 3 yang menunjukkan distribusi frekuensi pekerja pengelasan berdasarkan tingkat pengetahuan di PT Alim Ampuh Jaya Steel tahun 2016.

Tabel 3 menjelaskan bahwa responden yang memiliki tingkat pengetahuan dalam kategori baik berjumlah 13 orang $(65 \%)$, sedangkan 7 orang lainnya memiliki tingkat pengetahuan kurang baik $(35 \%)$.

\section{Tindakan}

Hasil kuesioner yang telah diperoleh dalam penelitian menjelaskan bahwa tindakan dari seluruh responden adalah tidak sesuai prosedur $(100 \%)$, tindakan yang dimaksud ialah tindakan pekerja dalam melakukan pekerjaannya apakah telah sesuai dengan prosedur yang telah ditetapkan PT Alim Ampuh Jaya Steel atau belum.

Tindakan keseluruhan pekerja tidak sesuai dengan prosedur pengelasan karena tidak tersedianya fasilitas pengelasan dan seluruh pekerja tidak melakukan kegiatan yang telah tertulis dalam prosedur seperti mengecek area kerja, mengikuti safety meeting sebelum bekerja dan seluruh pekerja bekerja tanpa ada ijin kerja panas atau hot work permit.

\section{Hubungan Umur dengan Tindakan}

Tabel 4. Hubungan Umur dengan Tindakan

\begin{tabular}{|c|c|c|c|c|}
\hline \multirow{2}{*}{$\begin{array}{c}\text { Umur } \\
\text { (Tahun) }\end{array}$} & \multicolumn{2}{|c|}{ Tindakan } & \multirow[b]{2}{*}{ Total } & \multirow[b]{2}{*}{$\%$} \\
\hline & $\begin{array}{c}\text { Tidak Sesuai } \\
\text { Prosedur }\end{array}$ & $\%$ & & \\
\hline$>34$ tahun & 9 & 45 & 9 & 45 \\
\hline$\leq 34$ tahun & 11 & 55 & 11 & 55 \\
\hline Total & 20 & 100 & 20 & 100 \\
\hline
\end{tabular}

Identifikasi hubungan antara umur responden dengan tindakan dilakukan untuk membuktikan bahwa karakteristik individu mempunyai indikasi sebagai salah satu faktor yang berhubungan dengan pengetahuan.

Tabel 4 menunjukkan bahwa responden yang paling banyak melakukan tindakan dengan tidak sesuai prosedur adalah kategori umur $\leq 34$ tahun yang berjumlah 11 orang $(55 \%)$. Hasil penelitian juga menunjukkan bahwa meskipun pekerja yang berumur relatif tua, masih melakukan tindakan yang tidak sesuai dengan prosedur.

\section{Hubungan Masa Kerja dengan Tindakan}

Identifikasi hubungan antara masa kerja responden dengan tindakan dilakukan untuk membuktikan bahwa karakteristik individu mempunyai indikasi sebagai salah satu faktor dari tindakan pekerja.

Tabel 5 menunjukkan bahwa meskipun pekerja yang memiliki masa kerja yang lama, masih melakukan tindakan yang tidak sesuai dengan prosedur.

\section{Hubungan Tingkat Pengetahuan dengan Tindakan}

Identifikasi hubungan antara tingkat pengetahuan dengan tindakan dilakukan untuk membuktikan bahwa tingkat pengetahuan mempunyai indikasi sebagai salah satu faktor dari tindakan pekerja.

Tabel 5. Hubungan Masa Kerja dengan Tindakan

\begin{tabular}{|c|c|c|c|c|}
\hline \multirow{2}{*}{$\begin{array}{c}\text { Masa Kerja } \\
\text { (Tahun) }\end{array}$} & \multicolumn{2}{|l|}{ Tindakan } & \multirow[b]{2}{*}{ Total } & \multirow[b]{2}{*}{$\%$} \\
\hline & $\begin{array}{c}\text { Tidak Sesuai } \\
\text { Prosedur }\end{array}$ & $\%$ & & \\
\hline$>7$ tahun & 5 & 25 & 5 & 25 \\
\hline$\leq 7$ tahun & 15 & 75 & 15 & 75 \\
\hline Total & 20 & 100 & 20 & 100 \\
\hline
\end{tabular}

Tabel 6. Hubungan Tingkat Pengetahuan dengan Tindakan

\begin{tabular}{lcccc}
\hline \multirow{2}{*}{$\begin{array}{c}\text { Tingkat } \\
\text { Pengetahuan }\end{array}$} & \multicolumn{2}{c}{ Tindakan } & Total & \% \\
\cline { 2 - 3 } & $\begin{array}{c}\text { Tidak Sesuai } \\
\text { Prosedur }\end{array}$ & $\%$ & & \\
\hline Baik & 13 & 65 & 13 & 65 \\
Kurang Baik & 7 & 35 & 7 & 35 \\
\hline Total & 20 & 100 & 20 & 100 \\
\hline
\end{tabular}


Tabel 6 menunjukkan bahwa responden dengan tingkat pengetahuan mengenai pekerjaannya pada kategori baik berjumlah 13 orang $(65 \%)$ namun memiliki tindakan yang tidak sesuai dengan prosedur pengelasan. Responden dengan tingkat pengetahuan kurang baik dan melakukan tindakan yang tidak sesuai dengan prosedur saat bekerja berjumlah 7 orang (35\%).

Berdasarkan hasil penelitian di atas, maka dapat diketahui bahwa meskipun pekerja memiliki pengetahuan yang baik tetap saja mereka melakukan tindakan yang tidak sesuai dengan prosedur pengelasan.

\section{PEMBAHASAN}

\section{Hubungan Umur dengan Tindakan}

Hasil penelitian menunjukkan bahwa pekerja dengan umur yang lebih tua masih banyak yang melakukan tindakan yang tidak sesuai dengan prosedur pengelasan.

Penelitian yang dilakukan oleh Kusuma (2013), menjelaskan bahwa umur berpengaruh dalam menentukan kondisi fisik, mental, kemauan kerja, dan tanggung jawab seseorang. Pekerja yang masih muda lebih peduli terhadap keselamatan dan kesehatannya, sedangkan usia yang lebih tua lebih bebas secara kewajiban sebagai pekerja.

Seharusnya pekerja yang lebih tua dapat memberi contoh bagi pekerja yang lebih muda dalam bekerja dengan aman, begitu juga pekerja yang lebih muda yang bekerja dengan aman atau sesuai dengan prosedur dapat menjadi contoh bagi pekerja sebayanya.

Kusuma (2013), menjelaskan bahwa seharusnya pekerja yang muda lebih memperhatikan keselamatannya dibanding pekerja yang lebih tua, sedangkan di penelitian ini menunjukkan bahwa tindakan yang tidak sesuai dengan prosedur pengelasan lebih banyak dilakukan oleh pekerja yang lebih muda.

Hasil wawancara dengan safety officer PT Alim Ampuh Jaya Steel menunjukkan bahwa pekerja yang lebih muda cenderung tidak peduli dengan keselamatan diri sendiri dalam bekerja seperti tidak memakai helm saat berada di area kerja dan sering merokok di area kerja.

Hasil penelitian yang menunjukkan bahwa umur muda ataupun tua tetap melakukan tindakan yang tidak sesuai dengan prosedur ini dikarenakan program K3 yang belum berjalan dengan baik dan fasilitas pengelasan yang telah disebutkan dalam prosedur pengelasan PT Alim Ampuh Jaya Steel seperti APAR dan fire blanket belum disediakan oleh perusahaan.

\section{Hubungan Masa Kerja dengan Tindakan}

Hasil penelitian menunjukkan bahwa pekerja dengan masa kerja yang lebih lama banyak melakukan tindakan yang tidak sesuai dengan prosedur pengelasan. Hasil ini tidak sesuai dengan teori Notoatmodjo (2012) yang menjelaskan bahwa semakin lama masa kerja tenaga kerja akan membuat tenaga kerja lebih mengenal kondisi lingkungan tempat kerja.

Pekerja dengan masa kerja lama otomatis telah mendapatkan banyak pengalaman selama bekerja, sehingga pengalaman tersebut dapat dijadikan pelajaran untuk bekerja lebih aman dengan bekerja sesuai prosedur yang ada. Selain itu, pekerja dengan masa kerja lama seharusnya memberikan contoh yang baik bagi pekerja lain terutama pekerja yang memiliki masa kerja singkat.

Hasil ini tidak sesuai dengan penelitian yang dilakukan oleh Kusuma (2013), yang menjelaskan bahwa seharusnya semakin lama seseorang bekerja semakin bertambah pengalaman dan ilmu mengenai pekerjaannya.

Hasil observasi dan wawancara juga menunjukkan bahwa pekerja yang meski memiliki pengalaman bekerja yang lama masih sering melakukan tindakan tidak aman seperti mengoperasikan overhead crane tanpa memiliki Surat Ijin Operasi (SIO) dan tanpa ijin kerja pengoperasian overhead crane. Banyaknya pekerja yang melakukan pekerjaan di luar posisinya atau jobdesc-nya dikarenakan belum diterapkannya work permit atau ijin kerja sehingga pekerja dapat melakukan pekerjaan yang di luar tugas dan kewajibannya.

Pekerja dengan masa kerja lama dan singkat seluruhnya melakukan tindakan pengelasan yang tidak sesuai dengan prosedur dikarenakan fasilitas dan program yang belum berjalan secara maksimal karena hambatan dari manajemen, seluruh pekerja pengelasan hanya melaksanakan poin dalam prosedur pengelasan yaitu memakai APD lengkap saat bekerja seperti apron, sarung tangan pengelasan, welding mask, safety shoes, dan respirator.

\section{Hubungan Tingkat Pengetahuan dengan Tindakan}

Hasil penelitian menjelaskan bahwa seluruh responden yang memiliki tingkat pengetahuan 
mengenai pekerjaannya pada kategori baik tetap melakukan tindakan yang tidak sesuai dengan prosedur pengelasan. Sedangkan pekerja yang mempunyai tingkat pengetahuan kurang baik juga melakukan tindakan yang tidak sesuai dengan prosedur pengelasan.

Notoatmodjo (2003), menjelaskan bahwa pengetahuan merupakan hasil dari tahu yang terjadi setelah orang melakukan pengindraan terhadap suatu objek tertentu. Pengetahuan kognitif merupakan domain yang sangat penting dalam membentuk tindakan seseorang.

Pengetahuan dari mayoritas pekerja memang sudah masuk dalam kategori yang baik, namun dalam bertindak saat melakukan pekerjaan belum sepenuhnya sesuai dengan prosedur yang telah dibuat oleh departemen K3. Poin yang telah dilaksanakan dengan baik oleh pekerja pengelasan di PT Alim Ampuh Jaya Steel adalah memakai APD lengkap seperti apron, gloves, safety shoes, welding mask, masker, dan baju kerja, namun poin yang lain seperti menyediakan perlengkapan pemadam kebakaran di dekat area kerja belum dilaksanakan. Pemakaian APD lengkap pada pekerja pengelasan ini telah sesuai dengan UU No. 1 tahun 1970 bab VIII pasal 12 poin $\mathrm{b}$ yang menjelaskan bahwa pekerja wajib memakai alat perlindungan diri yang sesuai.

Fasilitas yang mendukung dalam pelaksanaan pengelasan memang belum disediakan oleh perusahaan seperti APAR, fire blanket, selang dan pompa air. APAR yang ada di PT Alim Ampuh Jaya Steel hanya terdapat 20 buah yang ditempatkan di beberapa tempat, namun dalam pelaksanaan pekerjaan pengelasan tidak pernah ada APAR di dekat area kerja. Manajemen dan departemen K3 perlu melakukan peninjauan ulang terhadap prosedur pengelasannya dan menyediakan seluruh fasilitas yang menunjang pengelasan yang telah tertulis dalam prosedur.

Fasilitas seperti APAR sangat dianjurkan ada di dekat area kerja pengelasan sesuai peraturan dari NFPA 51B bagian 5 ayat 3 pasal 10 yang menjelaskan bahwa APAR yang telah terisi penuh, dapat digunakan dan sesuai dengan tipe bahaya harus tersedia di area kerja.

Kegiatan lain dalam prosedur yang belum terlaksanakan ialah penyediaan ijin kerja atau work permit terkait pekerjaan pengelasan, sehingga pekerja bekerja langsung tanpa ijin dari pengawas dan tanpa adanya ijin kerja ini, pengawas pengelasan tidak pernah memeriksa area kerja apakah boleh untuk bekerja atau tidak sesuai dengan poin di dalam prosedur pengelasan.

Ijin kerja pengelasan seharusnya diterapkan di PT Alim Ampuh Jaya Steel sesuai dengan ketentuan dari NFPA 51B bagian 4 ayat 2 yang menjelaskan bahwa manajemen seharusnya menerapkan ijin kerja atau permit authorizing individual dalam pekerjaan pengelasan. Work permit ini juga dapat mencegah pekerja pengelasan melakukan pekerjaan lain seperti yang sering terjadi di PT Alim Ampuh Jaya Steel, yaitu pekerja pengelasan melakukan pekerjaan lain seperti menggerinda, mengebor dan mengoperasikan overhead crane tanpa surat ijin operasi (SIO). Penerapan work permit atau ijin kerja ini juga bisa digunakan untuk sarana mengawasi pekerjaan di lapangan karena ijin kerja berisi persyaratan sebelum kerja hingga penilaian risiko pekerjaan.

Pengetahuan mengenai langkah kerja pengelasan yang aman, bahaya yang diakibatkan oleh pekerjaan pengelasan dan pengetahuan mengenai keselamatan kerja diperlukan agar pekerja memahami dan dapat menerapkan pengetahuan mengenai bekerja yang aman saat bekerja.

Pelatihan dan pemberian pendidikan mengenai bahaya akibat pekerjaan pengelasan dan cara untuk menanggulanginya dari manajemen dan departemen K3 akan sangat membantu dalam menambah wawasan pekerja yang diharapkan dapat diaplikasikan dengan baik saat bekerja. Pelatihan kepada pekerja seharusnya dilaksanakan oleh PT Alim Ampuh Jaya Steel mengingat UU No. 1 tahun 1970 bab V pasal 1 yang menjelaskan bahwa pengurus diwajibkan menyelenggarakan pembinaan bagi semua tenaga kerja yang berada di bawah pimpinannya, dalam pencegahan kecelakaan dan pemberantasan kebakaran serta peningkatan keselamatan dan kesehatan kerja, pula dalam pemberian pertolongan pertama dalam kecelakaan.

Pemberian materi mengenai keselamatan kerja tidak hanya melalui pelatihan saja, namun safety talk juga bisa dimanfaatkan untuk menyampaikan pesan mengenai pentingnya keselamatan kerja. PT Alim Ampuh Jaya Steel telah melaksanakan safety talk atau toolbox meeting setiap hari Senin guna memberikan materi tersebut, namun sebaiknya kegiatan tersebut dilaksanakan setiap hari sebelum pekerjaan dimulai agar pekerja selalu ingat dan informasi mengenai $\mathrm{K} 3$ dapat dilaksanakan saat bekerja. 


\section{SIMPULAN}

Pekerja dengan umur yang lebih tua masih banyak yang melakukan tindakan yang tidak sesuai dengan prosedur pengelasan. Seharusnya pekerja yang lebih tua dapat memberi contoh bagi pekerja yang lebih muda dalam bekerja dengan aman, begitu juga pekerja yang lebih muda yang bekerja dengan aman atau sesuai dengan prosedur dapat menjadi contoh bagi pekerja sebayanya.

Pekerja yang lebih muda cenderung tidak peduli dengan keselamatan diri sendiri dalam bekerja seperti tidak memakai helm saat berada di area kerja dan sering merokok di area kerja.

Pekerja dengan umur muda ataupun tua tetap melakukan tindakan yang tidak sesuai dengan prosedur ini dikarenakan program $\mathrm{K} 3$ yang belum berjalan dengan baik dan fasilitas pengelasan yang telah disebutkan dalam prosedur pengelasan di PT Alim Ampuh Jaya Steel belum disediakan oleh perusahaan.

Pekerja dengan masa kerja yang lebih lama banyak melakukan tindakan yang tidak sesuai dengan prosedur pengelasan. Pekerja dengan masa kerja lama otomatis telah mendapatkan banyak pengalaman selama bekerja, sehingga pengalaman tersebut dapat dijadikan pelajaran untuk bekerja lebih aman dengan bekerja sesuai prosedur yang ada. Selain itu, pekerja dengan masa kerja lama seharusnya memberikan contoh yang baik bagi pekerja lain terutama pekerja yang memiliki masa kerja singkat.

Pekerja dengan masa kerja lama dan singkat seluruhnya melakukan tindakan pengelasan yang tidak sesuai dengan prosedur dikarenakan fasilitas dan program yang belum berjalan secara maksimal karena hambatan dari manajemen, seluruh pekerja pengelasan hanya melaksanakan poin dalam prosedur pengelasan yaitu memakai APD lengkap saat bekerja seperti apron, sarung tangan pengelasan, welding mask, safety shoes, dan respirator.

Seluruh pekerja yang memiliki tingkat pengetahuan mengenai pekerjaannya pada kategori baik tetap melakukan tindakan yang tidak sesuai dengan prosedur pengelasan. Sedangkan pekerja yang mempunyai tingkat pengetahuan kurang baik juga melakukan tindakan yang tidak sesuai dengan prosedur pengelasan.

Pengetahuan dari mayoritas pekerja memang sudah masuk dalam kategori yang baik, namun dalam bertindak saat melakukan pekerjaan belum sepenuhnya sesuai dengan prosedur yang telah dibuat oleh departemen K3. Poin yang telah dilaksanakan dengan baik oleh pekerja pengelasan di PT Alim Ampuh Jaya Steel adalah memakai APD lengkap seperti apron, gloves, safety shoes, welding mask, masker, dan baju kerja, namun poin yang lain seperti menyediakan perlengkapan pemadam kebakaran di dekat area kerja belum dilaksanakan.

Fasilitas yang mendukung dalam pelaksanaan pengelasan memang belum disediakan oleh perusahaan seperti APAR, fire blanket, selang dan pompa air. APAR yang ada di PT Alim Ampuh Jaya Steel hanya terdapat 20 buah yang ditempatkan di beberapa tempat, namun dalam pelaksanaan pekerjaan pengelasan tidak pernah ada APAR di dekat area kerja. Manajemen dan departemen K3 perlu melakukan peninjauan ulang terhadap prosedur pengelasannya dan menyediakan seluruh fasilitas yang menunjang pengelasan yang telah tertulis dalam prosedur.

Pengetahuan mengenai langkah kerja pengelasan yang aman, bahaya yang diakibatkan oleh pekerjaan pengelasan dan pengetahuan mengenai keselamatan kerja diperlukan agar pekerja memahami dan dapat menerapkan pengetahuan mengenai bekerja yang aman saat bekerja.

Saran yang diberikan untuk perusahaan yaitu perusahaan disarankan untuk mengadakan program pelatihan bagi seluruh pekerja agar pekerja dapat memahami pekerjaan dan bahaya yang dapat ditimbulkan, sehingga pekerja dapat bekerja dengan aman dan dapat melaksanakan program K3 dari perusahaan. Perusahaan juga disarankan untuk menyediakan fasilitas yang menunjang aktivitas pengelasan seperti APAR dan fire blanket. Meninjau ulang prosedur pengelasan dengan menyesuaikan program yang telah diterapkan dan fasilitas yang telah ada di lapangan, agar tidak terdapat ketimpangan antara prosedur dan keadaan lapangan.

\section{DAFTAR PUSTAKA}

Green, L. 1980. Health education planning, A diagnostic Approach. California: Mayfield Publishing Co, pp. 71-80.

Heinrich, H.W. 1980. Industrial Accident Prevention. New York: McGraw-Hill Book Company.

Jamsostek. 2005. Peran Jamsostek dalam Membudayakan K3 di Indonesia. www.jamsostek. go.id. Sitasi: 9 September 2016.

Kusuma, R.Y. 2013. Hubungan antara Pengetahuan, Sikap, dan Kenyamanan dengan Penggunaan 
Alat Pelindung Wajah Pada Pekerja Las Listrik Kawasan Simongan Semarang. Skripsi. Fakultas Ilmu Kesehatan: Universitas Negeri Semarang.

Maanaiya, I. 2005. Faktor-Faktor yang Berhubungan dengan Tindakan Tidak Aman (Unsafe Action/ Substandard Practice) Pekerja di Bagian Press PT YIMM Tahun 2005. Tesis. Fakultas Kesehatan Masyarakat Universitas Indonesia: Depok.

Nasrullah, M., Tjipto, S. 2014. Hubungan antara Knowledge, Attitude, Practice Safe Behavior Pekerja dalam Upaya untuk Menegakkan Keselamatan dan Kesehatan Kerja. The Indonesian Journal of Occupational Safety and Health, Volume 3 Nomor 1, 82-93.

NFPA51B bagian 4 ayat 2 tentang Standard for Fire Preventing During Welding, Cutting, and Other
Hot Work 2003 Edition. Dallas: National Fire Protection Association.

Noer, R.W. 2012. Gambaran Perilaku Tidak Aman pada Pekerja di Unit Welding PT Gaya Motor, Sunter II, Jakarta Utara.

Notoatmodjo, S. 2003. Pendidikan dan Perilaku Kesehatan. Jakarta: Rineka Cipta.

Notoatmodjo, S. 2012. Pendidikan dan Perilaku Kesehatan. Jakarta: Rineka Cipta.

Presiden Republik Indonesia. Undang-Undang Republik Indonesia Nomor 1 Tahun 1970 tentang: Keselamatan dan Kesehatan Kerja.

Ramli, S. 2009. Sistem Manajemen Keselamatan dan Kesehatan Kerja OHSAS 18001. Dian Rakyat: Jakarta. 